\title{
Geoenvironmental assessment of urban water bodies
}

\author{
Elina Nasyrova ${ }^{1, *}$, Alexey Elizaryev ${ }^{1,2}$, Sergey Aksenov ${ }^{1}$, Yuriy Baiduk ${ }^{1}$, Elvira Kamaeva ${ }^{1}$, \\ and Rasul Akhtyamov ${ }^{3}$ \\ ${ }^{1}$ Ufa State Aviation Technical University, Ulitsa Karla Marksa, 12, Ufa, Respublika Bashkortostan, \\ 450077, Russia \\ ${ }^{2}$ Water Problems Institute, Russian Academy of Sciences, Moscow, Gubkina st., 3, 119333, Russia \\ ${ }^{3}$ Emperor Alexander I St. Petersburg State Transport University, Moskovsky Ave, 9, Sankt-Peterburg, \\ 190031, Russia
}

\begin{abstract}
Do you need clean water in your city? At last time, the quality of urban water bodies does not correspond to normative requirements. The government could not control state of all urban water bodies. Mainly, this is related with financial costs. In the study, the method of geoenvironmental assessment of water bodies is proposed. It is differ from others by including four stages (study of anthropogenic factors, morphometric study, hydrochemical and hydrobiological analysis). And most importantly, hydrochemical analysis including few main parameters, which were divided by priority. Meanwhile, each of this parameter can be easily analyzed on-site and do not need expensive laboratory equipment. The proposed method of geoenvironmental assessment considered by the example of pond Teploe (Ufa city, Russia).
\end{abstract}

\section{Introduction}

Water bodies within the urban landscape are subject to anthropogenic impact and represent a source of geoenvironmental hazard. In this paper, the geoenvironmental hazard of water bodies is considered as a manifestation of anthropogenic impact consequences, creating a threat to the geosystem.

Within the city, the following environmental (including anthropogenic) factors affect water bodies:

- chemical pollution caused by discharge of industrial and domestic waste water, unorganized surface runoff, littering of the coastal zone with solid municipal waste, etc.;

- recreational load;

- thermal pollution due to discharge of heated water from thermal power station.

All this factors lead to changes in the environmental situation of water bodies. Depending on the type of contamination, the authors suggest different methods of monitoring and water quality assess. For example, authors [1] proposed solution-oriented monitoring of chemical contamination of water bodies. Others in their work [2] consider low cost environmental monitoring in water bodies.

\footnotetext{
*Corresponding author: ElinaSagitovna@yandex.ru
} 
Guardo and Finizio, 2018 [3] proposed a new methodology combining historical series of monitoring data and GIS. But they mainly consider on pesticide. Aliloua et. all (2018) [4] offered cost-effective approach for selecting sampling locations.

In work we propose the following criteria of geoenvironmental hazard:

A - chemical pollution as a result of human economic activity;

$\mathrm{B}$ - thermal pollution of cooling water bodies due to discharge of heated water;

$\mathrm{C}$ - breakthrough of the soil dam forming the pond and flooding the lower beef.

According to the degree of geoenvironmental hazard water bodies are grouped:

1. $\mathrm{A}$ or $\mathrm{B}$ or $\mathrm{A}+\mathrm{B}$;

2. $\mathrm{A}+\mathrm{C}$ or $\mathrm{B}+\mathrm{C}$;

3. $\mathrm{A}+\mathrm{B}+\mathrm{C}$.

Thus the greatest geoenvironmental hazard for the city population is represented by water bodies included in the 3rd group. They are exposed to chemical and thermal pollution and having a soil dam.

To assess the state of water bodies in case of chemical pollution (criterion A of geoenvironmental hazard), the analysis of existing hydrochemical indicators of water quality was carried out. Each researcher in his work apply certain indicators to assess the water quality.

For example, authors [5] in their work assessed environmental quality by physicalchemical analyses (temperature, $\mathrm{pH}$, turbidity, conductivity, and total phosphorus) and microbiological analyses (E. coli). Mengxin et. all, 2018 [6] analyzed chemical oxygen demand, total nitrogen, total phosphorus and nitrogen-ammonia. In the work [7] analyzed such parameters as: $\mathrm{pH}$, flow velocity, conductivity, temperature, heavy metals $(\mathrm{Cu}, \mathrm{As}$, $\mathrm{Cd}, \mathrm{Pb}$ and $\mathrm{Zn}$ ), chemical oxygen demand, biological oxygen demand. We can see that each author use in his work different parameters.

Hydrobiological indicators, as well as hydrochemical ones, are widely used by researchers in assessing the state of urban water bodies.

Considering the geoenvironmental assessment as a parametric definition of the state of urban water bodies, ensuring the existence of the geosystem. In order to highlight the consequence of antropogenic impact on the background of natural processes. The authors propose a method of geoenvironmental assessment of water bodies.

\section{Methods}

The developed method of geoenvironmental assessment of urban water bodies includes the proposed criteria of geoenvironmental hazard and consists of four main stage.

1. Study of anthropogenic factors affecting to water body.

At the initial stage, the identification of main anthropogenic factors affecting to water body is carried out. Separation of anthropogenic factors by nature of pollution (chemical, physical, biological) and impacts (direct or indirect). At the same time, discharge of industrial wastewater is highlighted.

2. Morphometric study of water bodies.

Determination of morphometric parameters of water bodies (length, width and area) on a topographic map. According to obtained values of morphometric parameters and topographic map scale of at least 1:10000 in GIS programs built a three-dimensional model.

Classification of water bodies to establish water sampling points:

- areal object - water sampling points are located in the central nodes of the sectors into which it is initially divided;

- oblong object - water sampling points repeat its median line, with a minimum distance between them $100 \mathrm{~m}$.

The depth is measured at the established water sampling points. The obtained depth 
values determine the cross-section of the water body. Next, the required number of water sampling horizons for hydrochemical analysis is determined.

3. Hydrochemical analysis of water.

Taking into account the normative requirements and usage in the works. Widely used in practice hydrochemical indicators of water quality in the work were divided by priority.

I priority: temperature, dissolved oxygen, $\mathrm{pH}$, electrical conductivity;

II priority:

- permanganate oxidation - when there is no discharge of industrial wastewater into the object, with the exception of heated water from energy facilities;

- chemical oxygen demand, concentration of suspended solids, nutrient concentrations - if industrial wastewater are discharged;

III priority: concentration of pollutants, depending on the characteristics of the pollution source: heavy metals: $\mathrm{Pb}, \mathrm{Cu}, \mathrm{Zn}, \mathrm{Ni}, \mathrm{Cd}, \mathrm{Co}, \mathrm{Sb}, \mathrm{Hg}$; $\mathrm{Fe}, \mathrm{Cr}, \mathrm{As}, \mathrm{F}$; oil and petroleum products; phenol; synthetic surfactants; organochlorine and organophosphorus pesticides.

Thermal pollution of the water body used for discharge of heated water from electric power facilities is estimated in comparison with the background object. If the summer water temperature due to the discharge of heated water rises by more than $3^{\circ} \mathrm{C}$ compared to the background, there is thermal pollution.

Mapping of urban water bodies is carried out by using GIS programs. By spatial distribution of the analyzed hydrochemical indicators of water quality over the object area.

4. Hydrobiological analysis (floristic description).

For operational hydrobiological analysis, which does not require the collection of material and laboratory analysis, it is proposed to use macrophytes. Floristic description of urban water bodies is carried out according to common methods: the degree of overgrowth - according to the scheme of K. Starmach; abundance of species - on the scale of O.Drude. The features of macrophytes placement indicate the degree of anthropogenic factors influence. Taxonomic structure - the type of incoming pollutants. During the floristic description of water bodies, indicator species included in the list of Colquitz-Marsson are identified. The frequency of their occurrence is also determined. The saprobity index is calculated.

\section{Results and Discussion}

Let's analyze the proposed method of geoenvironmental assessment on the example.

The natural hydrographic network within the territory of Ufa city has 90 water objects of natural and artificial origin with an area of 0.1 to 84.0 ha. All urban objects are subject of anthropogenic impact. While the second group $(\mathrm{A}+\mathrm{B})$ of geoenvironmental hazard is a pond Dolgoe, and the third group - a pond Teploe.

Pond Teploe ( $54^{\circ} 47^{\prime}$ northern latitude, $56^{\circ} 6^{\prime}$ eastern longitude) is flowing, so there is a flow with rate $0.2 \mathrm{~m} / \mathrm{s}$. The basin of the pond is formed by a dredger. The bed of the object has a small slope (0.0025), clean and unclogged, earthen (clay, sand) with free flow. Roughness coefficient of the bottom is 0.0275 .

The average depth of the pond Teploe is $3.7 \mathrm{~m}$. The main morphometric indicators:

- surface area $0.25 \mathrm{~km}^{2}$;

- length $0.8 \mathrm{~km}$;

- width $0.25 \mathrm{~km}$.

From 1987 to the present time the water object is used for discharge of heated waters (direct-flow water supply system) (fig. 1). 


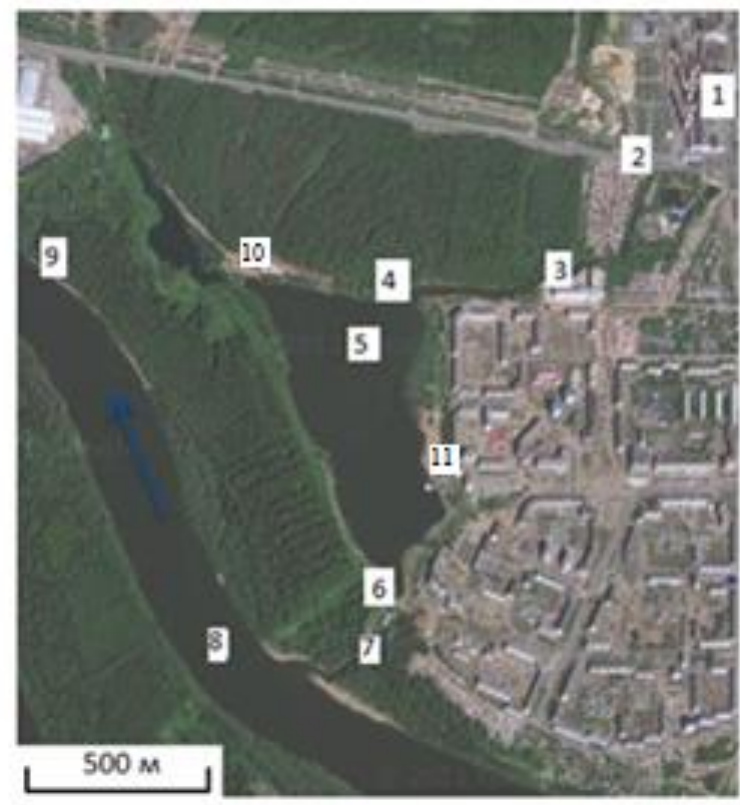

Fig. 1. Scheme of water discharge into the pond Teploe.

On the fig. 1: 1- power plant; 2 - point of discharge of heated water from power plant to the cooling channel; 3 - cooling channel; 4 - connection point of the cooling channel with the pond; 5 -Teploe pond; 6 - spillway mine; 7 - channel connecting the pond and the Ufa river; 8 - Ufa river; 9 - water intake point from the Ufa river; 10 - the recreation center; 11 - the beach.

Discharge of heated water is carried out through a system of closed reinforced concrete and open earthen channels to the Teploe pond. Then they go through the spillway mine in the Ufa river (fig. 1). The capacity of the spillway mine is $7 \mathrm{~m}^{3} / \mathrm{s}$ in normal operation and $11.7 \mathrm{~m}^{3} / \mathrm{s}$ in extreme situations (high water, flood). The pond is formed by a soil dam, which located after the spillway mine. On the bank is equipped beach and a recreation center (fig. 1).

1. Study of anthropogenic factors affecting to the Teploe pond.

The direct impact on pond Teploe is manifested in the form of a point discharge of heated waters. The area impact on the object is a recreational load. A linear source of pollution is unorganized surface runoff from the catchment area. Contaminated industrial wastewater is not discharged into the pond Teploe.

2. Morphometric study of the pond Teploe.

In the GIS program Surfer 9.0 by topographic map of Ufa city (scale 1:10000) taking into account the basic morphometric parameters built three-dimensional model of object (fig. 2). 


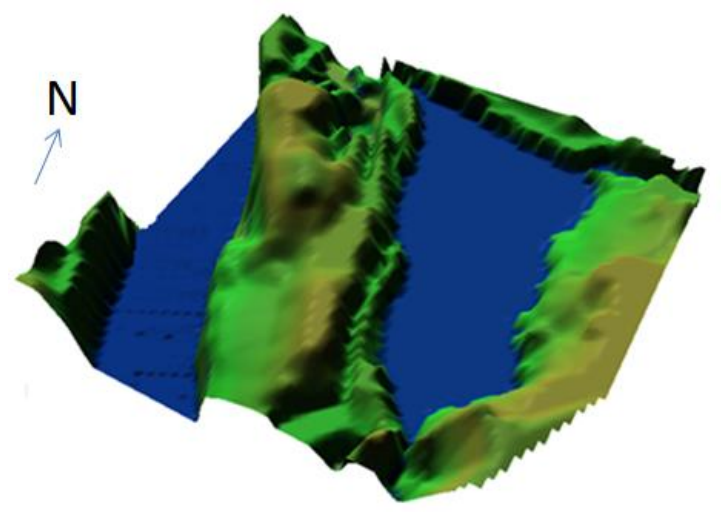

Fig. 2. Three-dimensional model of pond Teploe.

As can be seen from fig. 2, the relief of the catchment is homogeneous. In accordance with the hypsometric characteristics of the surface the catchment is lowland. On the NorthWest side, the nanorelief of the catchment surface is presented by small erosion furrows. The West bank is low, steep and abrasive. The Northern and Eastern shores are flat and low-lying. The North-Eastern shore is weak and characterized by waterlogging. The Eastern shore is sandy, in this part there is a beach.

The microrelief of the South-Eastern part is presented by a low coast shaft. In the SouthEastern part of the pond after the coastal shaft observed erosion furrow, providing surface runoff. The Southern and North-Western shores are bordered by a sandbank. The presence of a gentle shore and a slope are reason to surface runoff.

The pond Teploe is an areal object, so the sampling points were located in the central nodes of the sectors into which it is initially was divided (fig. 3).

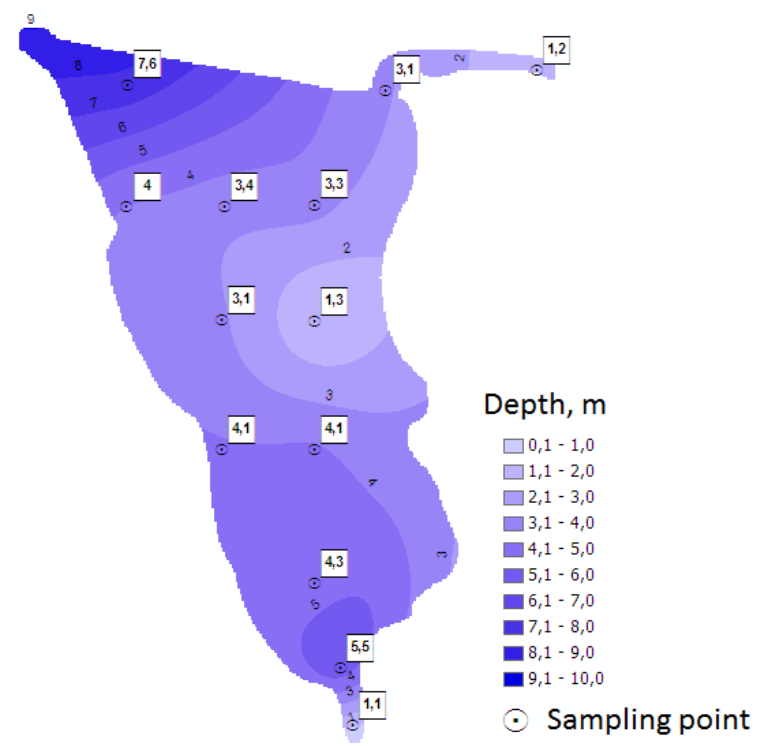

Fig. 3. Spatial distribution of depth.

Since the average depth of the pond Teploe is $3.5 \mathrm{~m}$, i.e. does not exceed $5 \mathrm{~m}$. Installed one sampling horizon at the water surface: at a depth of $0.3 \mathrm{~m}$ from the surface. In which water samples were taken and the water temperature was measured.

According to the obtained data of the pond depth, the cross sections corresponding to 
the water sampling points are constructed. The sections are trapezoidal.

3. Hydrochemical analysis of water.

Since contaminated industrial wastewater does not discharge to the pond Teploe, in the the work analyzed the hydrochemical indicators of water quality I and II priority. Namely: temperature, $\mathrm{pH}$, concentration of dissolved oxygen, electrical conductivity and permanent oxidability by seasons. $\mathrm{pH}$, electrical conductivity and permanganate oxidation of the water samples were measured using common methods. Water temperature and dissolved oxygen concentration were measured during water sampling at the object.

To quantify the criterion of geoenvironmental hazard $\mathrm{B}$, the analysis of thermal pollution of the pond Teploe was carried out. There are no gauging stations on the water bodies within the Ufa city. Comparison of the summer water temperature in the pond Teploe and in the background object is made. Background object is a pond Dolgoe (Ufa city, Russia) which is not subject to thermal pollution. The average water temperature of the ponds in June and August (2011-2012) presented in table 1.

Table 1. Average summer water temperature $\left({ }^{\circ} \mathrm{C}\right)$.

\begin{tabular}{|c|c|c|c|c|}
\hline \multirow{2}{*}{ Year } & \multicolumn{2}{|c|}{ Pond Teploe } & \multicolumn{2}{c|}{ Pond Dolgoe } \\
\cline { 2 - 5 } & June & August & June & August \\
\hline 2011 & 26.9 & 29.2 & 20.2 & 23.3 \\
\hline 2012 & 27.2 & 29.4 & 23.8 & 23.3 \\
\hline
\end{tabular}

As can be seen from table 1 , there is an excess of the summer temperature of pond Teploe more than $3{ }^{\circ} \mathrm{C}$. Which indicates the thermal pollution of the pond Teploe due to the discharge of heated waters.

According to the experimental data obtained, the spatial distribution of the analyzed hydrochemical parameters over the area of the pond Teploe with the application of isolines in the ArcGis 9.3.1 program was performed. As an example, the mapping of the pond Teploe for $\mathrm{pH}$ is given (fig. 4).

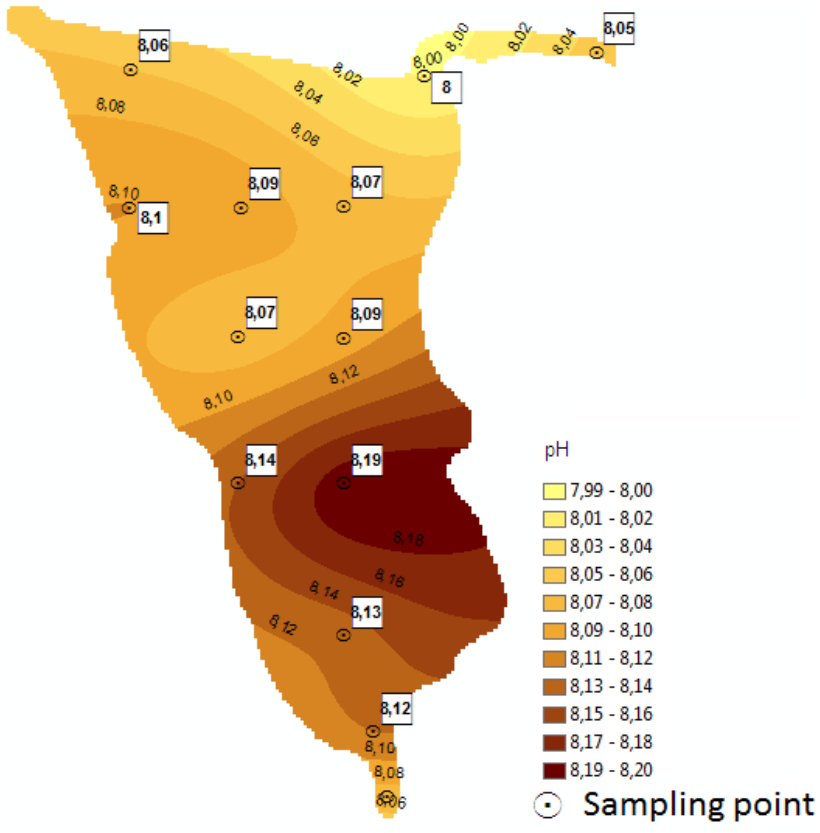

Fig. 4. The distribution of pH over the pond area in August 2011. 
As can be seen from fig. 4, the gradient of increasing the $\mathrm{pH}$ in August 2011 is directed from the discharge place of heated water to the spillway mine. The maximum value is fixed in the recreational area.

4. Hydrobiological analysis (floristic description).

By the results of field studies of pond Teploe in June 2011 and 2012, floristic composition includes 13 species of higher aquatic plants belonging to 11 families. Concentration of higher aquatic vegetation is observed in the littoral zone of the pond. The main community of helophytes is the association of common reed with aquatic plants (Phragmtietum australis aqui-herbosum) in the the North-Western part. The South-Western part is reed with water plants (Scirpus lacustris aqui-herbosum). Community of hidtorical ceratophyllum with water plants (Ceratophyllum demersum aqui-herbosum).

The overgrowing degree of pond Teploe by Starmach in 2011 and 2012 is 1 point, i.e. $2 \%$ of the total area. Overgrowth by macrophytes up to $10 \%$ of the total area, uneven type (sparse groups). During the floristic description of the pond Teploe the indicator species included in the list of Colquitz-Marsson were identified. Their frequency of occurrence was determined.

As a result of the hydrobiological study the saprobity index of the pond Teploe in 2011 and 2012 is 1.73 , i.e. the pond is $\beta$-mesasaprobe (1.5-2.5). In accordance with the scale of the saprobity index for the quality class, the pond Teploe is moderately polluted.

\section{Conclusion}

The hydrochemical indicators of water quality included in group I and II priority (concentration of dissolved oxygen, $\mathrm{pH}$, electrical conductivity of water and permanganate oxidability) and hydrobiological indicators (saprobity index) allow us to classify pond Teploe by quality class, trophic status and saprobity character.

However, according to the received data it is difficult to clearly determine the state of water bodies. For example, the results of hydrochemical and hydrobiological analysis revealed that by the concentration of dissolved oxygen pond Teploe (18.11.2010) was "very clean", the $\mathrm{pH}$ - "moderately polluted", the conductivity of water-"very clean", the permanganate oxidation is also "very clean", the saprobity index - "moderately polluted".

On the other hand, the obtained results of mapping together with the three-dimensional model and the results of hydrochemical and hydrobiological analyses allow to analyze the geoenvironmental situation on the object. To assess its change under the influence of both anthropogenic factors and abiotic and biotic.

The next step of research it is developing complex indicator, that allow uniquely assess the state of water body.

The presented research was financially supported by the Russian Science Foundation (grant no. 17-77-30006).

\section{References}

1. W. Brack, B.I. Escher, E. Müller, M. Schmitt-Jansen, T. Schulze, J. Slobodnik, H. Hollert, Environ. Sci. Eur. 30, 33 (2018) doi.org/10.1186/s12302-018-0161-1

2. M.V. Japitana, E.V. Palconit, A.T. Demetillo, M. Edgar C. Burce, E.B. Taboada, M. Lochinvar, S. Abundo, Nat. Environ. Pollut. Technol. 17, 4 (2018)

3. A. Di Guardo, A. Finizio, Sci. Total Environ. 610-611 (2018) doi.org/10.1016/j.scitotenv.2017.08.049

4. H. Aliloua, A.M. Niaa, H. Keshtkard, D. Hanb, M. Brayc, Sci. Total Environ 624 (2018) 
5. R.R. Vargas, M. da Silva Barros, A.R. Saad, R. de O. Moraes Arruda, F. Dall'Ara Azevedo, J. Appl. Sci. 13, 2 (2018) doi.org/10.4136/ambi-agua.2131

6. M. Kang, Y. Tian, H. Zhang, D. Wang, IOP Conference Series: Earth and Environ. Sci. 112, 1 (2018)

7. C. Oualid, M. Abdellah, El O. Alami Abdelhakim, El A. Ilham, O. Bouchra, Int. J. Appl. Eng. Res. 13 (2018) 